\title{
Generic Model of Fuzzy Profile Matching for Determining the Best Marketer
}

\author{
Sherly Oktafiani ${ }^{1}$, Ditdit Nugeraha Utama ${ }^{2}$ \\ ${ }^{1}$ Computer Science Department, BINUS Graduate Program - Master of Computer Science Bina Nusantara \\ University, Jakarta, Indonesia 11480; sherly.oktafiani@ binus.ac.id \\ ${ }^{2}$ Computer Science Department, BINUS Graduate Program - Master of Computer Science Bina Nusantara \\ University, Jakarta, Indonesia 11480; ditdit.utama@binus.edu
}

\begin{abstract}
Marketer is practically desirable as an imperative function to support prosperity and increase company profits, intensely for production company. Thus, a selection process for top-marketer as a motivating compensation offered by company is an interesting study to conduct. Here, this study, by operating a combination of fuzzy-logic with profile-matching method, was performed to propose a decision model to help a company in deciding a top-marketer. Step-by-step ways to merge a combination of fuzzy-logic and profile-matching methods will be verified to decide feasibility of a top-marketer. Where through this method, marketers who have ideal standards that are in accordance with the needs of the company will be determined scientifically. Thru piece-by-piece mathematical procedure, five examples of selected-parameter, and then realized in two top-marketers selection case, purposely in medical equipment distribution company, are delivered as an example of measurement.
\end{abstract}

Key words: marketer, decision support model, fuzzy-logic, profile-matching.

\section{INTRODUCTION}

This research is a small part of a large study of decision-making systems. Where, this sub-study emphasizes a discussion of methods that are officially operated in the process of selecting top-marketers, intensely in the case of medical equipment distributors. As is known, that marketing department is a very important function that is capable of supporting the company's achievement [1].

Marketers practically allow for customer-focused interactions by creating factors that contain attractiveness tailored to the company's strategy [2], as well as providing a positive impact through a process of developing long-term relationships based on interaction marketer activities [3]. This is able to have a stronger influence on marketing strategies and positive implications for business [3], which greatly motivate a company's growth. If the performance of marketer is good, then the company's growth is also going to be much better. When marketing department maximizes its business performance, creative marketing strategies will emerge. These conditions are going to support to achieve effective implementation of the company's strategy [4].

Based on technological developments, many ways have been taken by several organizations to help optimize the marketing department. Among others, by implementing a decision support system (DSS) in e-tourism applications to help decide which tourist destinations are most suitable for the interests of customers [5]. Then, the application of the Mehrabian-Rusel (MR) method in the marketing support system (MDSS) is useful to examine weather factors in influencing consumer buying interest [6].

In addition, an application of geographic information systems (GIS) in marketing information systems serves as a tool in decision making when deciding strategic locations to increase attractiveness for customers [7]. There is also an application of customer decision making (CDM) using model P6 for customers to clarify web services that suit their needs [8], then there is also decision-making systems based on the dissemination of advertising through social media to bring up advertisements according to user habits [9][10].

However, from a several cases that helped improving a quality of company's business, there was no single discussion in the marketing department itself. As we all know, marketer is an important point in improving the quality of company's business [11]; hence research in various marketing fields to find out who is the best marketing agent in a company through DSS is academically feasible. Practically, it is able to grow and motivate marketing agents (hereinafter referred to as marketers) to compete with each other and become more productive in marketing the company's products, thus the company's vision and mission are predictably achieved. Furthermore, DSS to determine the best marketers (top-marketers) is able to be exploited to provide incentives (bonuses) carried out by the company.

The right method is necessitated to get the right result. For this reason, the concept of DSS is academically exploited by applying a combination of fuzzy-logic (FL) methods and profile-matching (PM). Where these methods have a 
function to carry out the main approach in determining the objectives of the decision.

Therefore, in this sub-study, a fuzzy profile matching (FPM) scheme is produced. It is utilized as a chosen step solving top-level problems in determining top-marketers. FL is technically desirable to handle data ambiguity, so the data entered in the decision model is more valid. While PM itself is a profitable method as a benchmark for adjusting ideal marketer criteria in a company used by top management to determine top-marketers.

\section{RELATED WORKS}

In the current era, technology has expended and developed rapidly, especially in the marketing departments. The company has launched many efforts in marketing management in building strong bonds to encourage loyalty [12]. With a marketing system, companies are able to collect data related to the external marketing environment that calculated as macro and micro factors [7]. Management's decisions usually involve intangible variables [13], allowing marketing management to utilize the marketing theory underlying the model [14].

The following is also said by [6] that increasing the effectiveness of customer segmentation may be done through MDSS techniques and models; and through knowledge management $(\mathrm{KM})$ also to use new knowledge in making decisions about appropriate marketing criteria [8]; or use of DSS in tourism marketing management [5]. In addition, using the GIS model in determining strategic marketing locations [6] has also been operated, besides that there is also the implementation of $\mathrm{CDM}$ in making decisions to determine appropriate web services [8].

Then DSS has been used as a basis for optimal planning in operational decision making [15], also reliable for industry practitioners in decision making [16]. It serves to produce quality improvements for efficient workflows, tailored reporting, relativity shorter time, and minimize user errors [17].

The application of DSS extends to several sectors. This is able to be employed by travel agents through the e-tourism system to help tourists that are according to their wishes. The choice of this goal can be used as a marketing strategy in creating an e-tourism system to make tourists easier to make decisions when choosing tourist destinations [5].

The high level of competition in marketing also adopts MDSS as something worth considering in increasing sales value [6]. For this reason, weather factors become a reference in decision making. Relating to environmental stimuli that affect consumer emotions, this will be very beneficial for retailers to promote products during low sunlight, high temperatures and poor air quality conditions [6].
GIS in marketing planning and decision making based on strong visual presentation and the relationship of spatial analysis used in marketing information systems as a tool for decision-making processes [7]. The aim is to improve text tables and communication by presenting data visually and informally, thus ensuring that accurate results are obtained quickly, which in turn leads to better and more appropriate decisions [7].

Competition in the business environment requires intelligent decision-making about changes in the environment and organizations that are appropriate to the needs. Therefore, the $\mathrm{KM}$ system is needed to obtain, store, retrieve, and use the latest knowledge, which might help organizations collect, process, and use knowledge with high accuracy, speed, and efficiency [8].

CDM helps customers make decisions as a determinant of successful web services [18]. Because marketing through social networks can reach most customers quickly. Customer network data can be used as a reference in making decisions to select influencers and spread pathological viruses that make viral messages replicate themselves [9]. Message deployment is used as a media marketing campaign to achieve the maximum number of message shipments through data mining with the classification method. As a result, decision-making systems can recommend the most appropriate measure in describing a customer's ability to spread the message [9].

Application of the supply chain model (SC) in combining business strategy decision components to gain competitive advantage in global markets [19]. This is done to reduce the relevance of the trade-off assessment that exists between demand and SC investment capacity needed to meet demand through this technique, models based on descriptive data for marketing activities can be obtained for later use in the optimization scheme [19].

Increase the income of online marketing media companies in increasing accountability to understand and analyze the behavior of market developments through online video, video growth patterns, and can predict prospects for the future [10].

DSS can also be handled by certain methods which include the application of CBR methods as evaluation factors and choices [5]. CBR is a knowledge-based system that uses previous cases to interpret new problems [20]. Where this method is carried out will produce intelligent integrated modules that can help customers choose travel destinations during the decision-making process. CBR allows the use of specialized knowledge by remembering the same thing before in positioning and reusing knowledge about the position [5].

And then, AHP method as a group decision-making method used in project selection to evaluate several complex alternative criteria [21]. This method provides an estimate of 
the hurdle rank [22]. This is a hierarchical decision-making model with the final results in the form making scores obtained from each project [21]. As accuracy in handling ambiguity and obscurity in the decision-making evaluation process, this fuzzy AHP approach is used as a DSS evaluation [23].

\section{LITERATURE REVEW}

\subsection{Fuzzy Logic}

FL was discovered by Prof. Lotfi Zadeh from the University of California at Barkeley in mid-1960, that true and false laws of Boolean logic were not in accordance with real conditions [24]. Boolean reasoning themselves are conceptually related to unclear truths [25]. FL is part of artificial intelligence (AI) that is capable of capturing uncertainty or ambiguity into linear values, FL is used to assess opinions based on human assumptions [26]. The FL method itself is a classification and algorithm of the state of ambiguity in data grouping [27]. Likewise, it is revealed by [28] that fuzzy is able to be benefitted as a method to develop DSS models based on unexplained gray human language. The application of FL methods is executed because of its ability to capture uncertainty [29]. FL describes the most obscure variables so that can help in estimating reasons [30].

\subsection{Profile Matching}

PM is a multi-criteria analysis method with each criterion centered on values in determining the order of priorities [31]. PM is a DSS method that assumes there is an ideal predictor level that must be gathered by parameters [32], which broadly compares marketer competencies with aspects that can be known as differences (gaps). In general, PM used as a mechanism in decision making assuming the level of predictor variables that must be met by the research subject [33]. GAP is a distinction between profile marketers and target values. As revealed [32], the gap is a disparity between the value of the aspect and the target value. The gap itself is measured via equation (1); where $\delta$ is a gap, $\mu$ represents a marketing profile, and $\tau$ is a target value.

$$
\delta=\mu-\tau
$$

After obtaining each gap for each profile of the marketer, each profile is given a value weight with a benchmark tables of weight value gap as can be seen in Table 3. Where if the gap is 0 then weight of the value is 5 , which means there is no difference or competency as needed. Then if gap 1then weight of the value is 4.5 , gap - 1 then weight of the value is 4 , gap 2 then weight of the value is 3.5 , gap -2 then weight of the value is 3 , gap 3 then weight of the value is 2.5 , gap -3 then weight of the value is 2 , gap 4 then weight of the value is 1.5 and if the gap is -4 , the weight of value is 1 .
Table 1: Weighting Tables [31]

\begin{tabular}{|c|r|c|l|}
\hline No & Gap & Weight & Description \\
\hline 1 & 0 & 5.00 & Competencies as needed \\
\hline 2 & 1 & 4.50 & Competencies over 1 level \\
\hline 3 & -1 & 4.00 & Competencies lack 1 level \\
\hline 4 & 2 & 3.50 & Competencies over 2 level \\
\hline 5 & -2 & 3.00 & Competencies lack 2 level \\
\hline 6 & 3 & 2.50 & Competencies over 3 level \\
\hline 7 & -3 & 2.00 & Competencies lack 3 level \\
\hline 8 & 4 & 1.50 & Competencies over 4 level \\
\hline 9 & -4 & 1.00 & Competencies lack 4 level \\
\hline
\end{tabular}

Determining the criteria of marketer is done based on review activity from several papers. It aimed to obtain a number of criteria commonly used in defining one's profile. Table 2 presents the results of the review activity that have been adjusted to the theme of this research.

Table 2: Criteria attribute

\begin{tabular}{|r|l|l|}
\hline No & \multicolumn{1}{|c|}{ Criteria } & \multicolumn{1}{|c|}{ Authors } \\
\hline 1 & Education & {$[34]$} \\
\hline 2 & $\begin{array}{l}\text { Verbalization idea, cooperation, } \\
\text { social }\end{array}$ & $\begin{array}{l}{[34],[35], \text { and }} \\
{[36]}\end{array}$ \\
\hline 3 & Reasoning and real solution & {$[34]$} \\
\hline 4 & $\begin{array}{l}\text { Concentration, attitude to work, } \\
\text { interest, personality }\end{array}$ & $\begin{array}{l}{[34],[37],[35],} \\
\text { and [36] }\end{array}$ \\
\hline 5 & Creativity of imagination & {$[34]$} \\
\hline 6 & Anticipation & {$[34]$} \\
\hline 7 & Years, years of service & {$[34]$ and [38] } \\
\hline 8 & Accuracy and responsibility & {$[34]$} \\
\hline 9 & Ethics, behavior & {$[34]$} \\
\hline 10 & $\begin{array}{l}\text { Encouragement of } \\
\text { achievement, work achievement }\end{array}$ & {$[34],[35]$, and } \\
\hline 11 & $\begin{array}{l}\text { Vitality and planer, quality of } \\
\text { work }\end{array}$ & {$[34],[36]$, and } \\
\hline 12 & Discipline & {$[35]$} \\
\hline 13 & Work experience & {$[34]$} \\
\hline 14 & Attitude toward company & {$[35]$} \\
\hline 15 & Quantity of work & {$[35]$} \\
\hline 16 & Knowledge of work, learning & {$[35]$ and [36] } \\
\hline 17 & management & $\begin{array}{l}\text { Work setting, evaluation and } \\
\text { reporting }\end{array}$ \\
\hline 18 & Reliable & {$[35]$ and [36] } \\
\hline 19 & Initiative & {$[35]$} \\
\hline 20 & Competitive & {$[36]$} \\
\hline & & \\
\hline
\end{tabular}

\section{RESEARCH FRAMEWORK}

In conducting research, to get the results as expected, a research framework is practically required. Where the framework of the research conducted in this study is based on the stages in Figure. 1. Where Figure. 1. illustrates four 
important criteria in the study: research objectives, results, activities or stages, and methods used in each of the research activities.

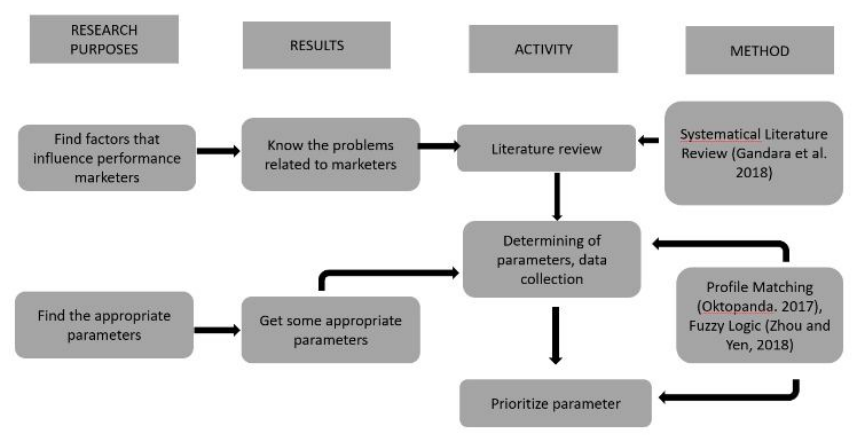

Figure 1: Research phase

This framework is a small part of a large framework, where this framework focuses more on developing the research method itself. Where research is conducted with a focus on the problem you want to solve. Furthermore, a systematic literature review is carried out to approach problem and find studies that already existed or related before. Based on this, the appropriate parameters are found to solve the problem and can choose one of the appropriate problem-solving methods. Use either SI (MKS) or CGS as primary units.

\section{RESULT AND DISCUSSION}

\subsection{Weighting Value of Fuzzy}

Determine the fuzzy value that just states true or false, there is no explanation between. It is intended that the input of absolute values in PM method is more relevant and there is no ambiguity. Following adoption of fuzzy logic to determine the criteria of marketers.

Then, how data is able to be applied with fuzzy is going to be explained. Five criteria are taken to show fuzzy application.

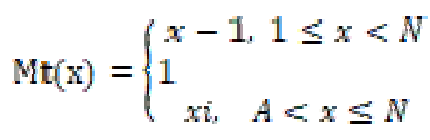

In this study, triangular membership functions were operated (like in [39], [40], and [41]). For membership function of fuzzy values for educational criteria is configured in Figure. 2. Where, Figure. 2. describes the level of member (X) which intersects the axis $(\mathrm{Y})$ of education criteria consisting of should out (SN), welcome (W), very allowed (VA) with fuzzy values $(1,1,2),(1,2,3)$ and $(2,3,3)$ respectively.

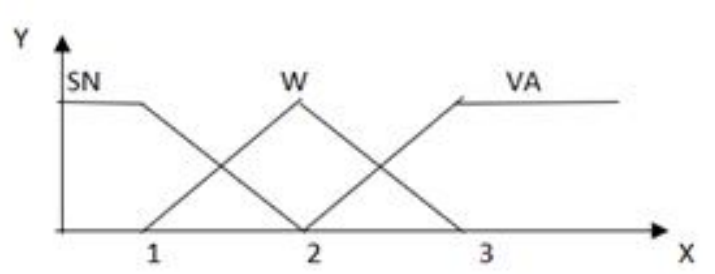

Figure 2: Membership Function for Criteria 1 - Education

For the measuring pair of criteria 1, there is a goodness level can be seen in Figure 3. Membership with member (X) which intersect the axis $(\mathrm{Y})$ is unacceptable $(\mathrm{U})$, just acceptable (JA), very Good (VG) with the fuzzy values are correspondingly $(1,1,2),(1,2,3)$ and $(2,3,3)$.

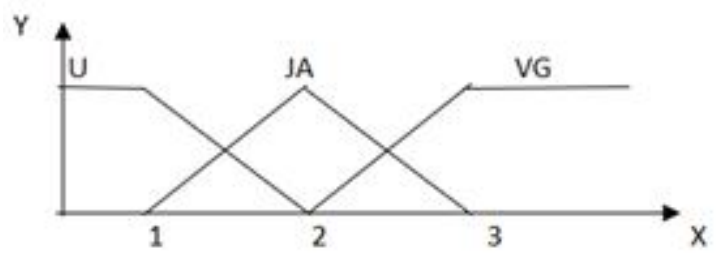

Figure 3: Membership Function for Goodness of criteria 1

Furthermore, the fuzzy rule bases are determined. The rule bases for Education VS Goodness are regulated in Rule 1 as follow or listed in Table 3.

Rule 1: Fuzzy Rule Bases for Education VS Goodness IF (Edu is SN) THEN

(Goodness is $\mathrm{U}$ )

ELSEIF (Edu is SN) or (Edu is W) THEN

(Goodness is $\mathrm{U}$ )

ELSEIF (Edu is W) THEN

(Goodness is JA)

ELSEIF (Edu is W) or (Edu is VA) THEN

(Goodness is JA)

ELSEIF Edu is VA THEN

(Goodness is VG)

Table 3: Education VS Goodness

\begin{tabular}{|c|l|l|}
\hline No. & Education & Goodness \\
\hline 1. & SN & U \\
\hline 2. & SN or W & U \\
\hline 3. & W & JA \\
\hline 4. & W or VA & JA \\
\hline 5. & VA & VG \\
\hline
\end{tabular}

For membership of fuzzy values from verbalization idea criteria can be seen in Figure 4. Where describes the level of member $(\mathrm{X})$ which intersects the axis $(\mathrm{Y})$ of verbalization idea criteria consisting of very low (VL), low (L), just acceptable (JA), Quite a lot (QL), many (M) with fuzzy values are individually $(5,5,10),(5,10,15),(10,15,20),(15,20$, $25)$ and $(20,25,25)$. 


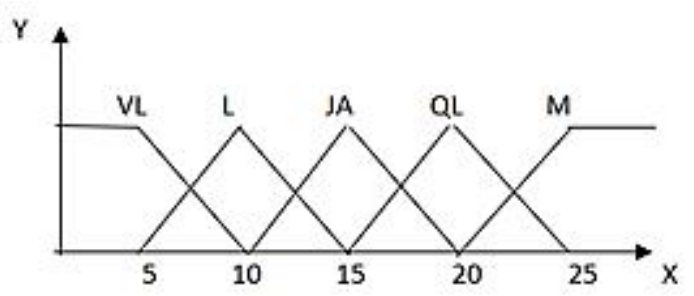

Figure 4: Membership Function for Criteria 2 - Verbalization idea For the measuring pair of criteria 2, there is a goodness level can be seen in Figure 5. Membership with member $(\mathrm{X})$ which intersect the axis (Y) is unacceptable (U), barely acceptable (BA), just acceptable (JA), good $(\mathrm{G})$, very Good $(\mathrm{VG})$ with the fuzzy values are separately $(1,1,2),(1,2,3),(2,3,4),(3$, $4,5)$ and $(4,5,5)$.

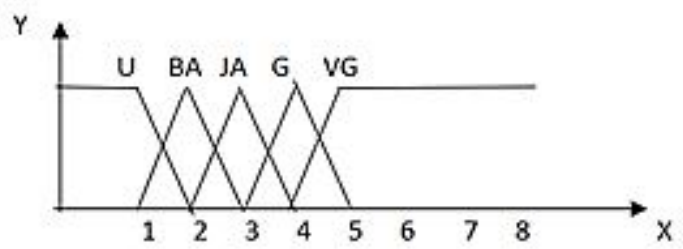

Figure 5: Membership Function for Goodness of criteria 2

Furthermore, the rule bases for Idea Verbalization (IV) VS Goodness are regulated in Rule 2 or listed in Table 4.

Rule 2: Fuzzy Rule Bases for Idea Verbalization VS Goodness

IF (IV is VL) THEN

(Goodness is $\mathrm{U}$ )

ELSEIF (IV is VL) or (IV is L) THEN

(Goodness is U)

ELSEIF (IV is L) THEN

(Goodness is BA)

ELSEIF (IV is L) or (IV is JA) THEN

(Goodness is BA)

ELSEIF (IV is JA) THEN

(Goodness is JA)

ELSEIF (IV is JA) or (IV is QL) THEN

(Goodness is JA)

ELSEIF (IV is QL) THEN

(Goodness is $\mathrm{G}$ )

ELSEIF (IV is QL) or (IV is M) THEN

(Goodness is $\mathrm{G}$ )

ELSEIF (IV is M) THEN

(Goodness is VG)

Table 4: Idea Verbalization VS Goodness

\begin{tabular}{|c|l|l|}
\hline No. & Verbalization Idea & Goodness \\
\hline 1. & VL & U \\
\hline 2. & VL or L & U \\
\hline 3. & L & BA \\
\hline 4. & L or JA & BA \\
\hline 5. & JA & JA \\
\hline 6. & JA or QL & JA \\
\hline
\end{tabular}

\begin{tabular}{|l|l|l|}
\hline 7. & QL & G \\
\hline 8. & QL or $\mathrm{M}$ & $\mathrm{G}$ \\
\hline 9. & $\mathrm{M}$ & $\mathrm{VG}$ \\
\hline
\end{tabular}

For membership of fuzzy values from quantity of work criteria can be seen in Figure 6. Where describes the level of member (X) which intersects the axis (Y) of quantity of work criteria consisting of low (L), just acceptable (JA), many (M) with fuzzy values are respectively $(10,10,20),(10,20,30)$ and $(20,30,30)$.

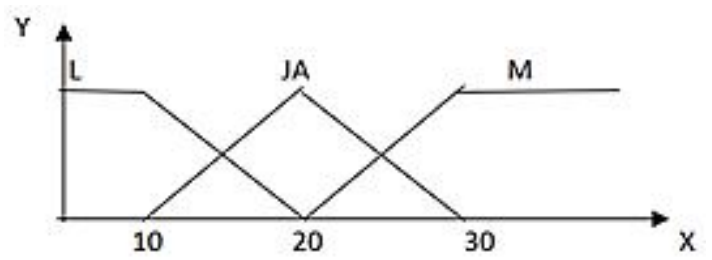

Figure 6: Membership Function for Criteria 3 - Quantity of work

For the measuring pair of criteria, there is a goodness level can be seen in Figure 7. Membership with member (X) which intersect the axis $(\mathrm{Y})$ is unacceptable $(\mathrm{U})$, good $(\mathrm{G})$, very Good (VG) with the fuzzy values are singly $(1,1,2),(1,2,3)$, and $(2,3,3)$.

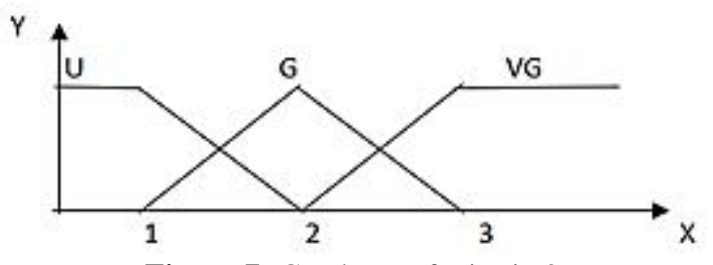

Figure 7: Goodness of criteria 3

Moreover, the rule bases for Quantity of Work (QOW) VS Goodness are determined via Rule 3 or listed in Table 5.

Rule 3: Fuzzy Rule Bases for Quantity of Work VS Goodness IF (QOW is L) THEN

Goodness is $\mathrm{U}$

ELSEIF (QOW is L) or (QOW is JA) THEN

Goodness is $\mathrm{U}$

ELSEIF (QOW is JA) THEN

Goodness is $\mathrm{G}$

ELSEIF (QOW is JA) or (QOW is M) THEN

Goodness is $\mathrm{G}$

ELSEIF (QOW is M) THEN

Goodness is VG

Table 5: Quantity of Work VS Goodness

\begin{tabular}{|c|l|l|}
\hline No. & \multicolumn{1}{|c|}{ QOW } & Goodness \\
\hline 1. & L & U \\
\hline 2. & L or JA & U \\
\hline 3. & JA & G \\
\hline 4. & JA or M & G \\
\hline 5. & M & VG \\
\hline
\end{tabular}


For membership of fuzzy values from reasoning and real solution criteria can be seen in Figure 8. Where describes the level of member $(\mathrm{X})$ which intersects the axis $(\mathrm{Y})$ of reasoning and real solution criteria consisting of very young (VY), young $(\mathrm{Y})$, mature $(\mathrm{M})$, old $(\mathrm{O})$, very old $(\mathrm{VO})$ with fuzzy values are correspondingly $(30,30,60),(30,60,90),(60,90$, $120),(90,120,150)$, and $(120,150,150)$.

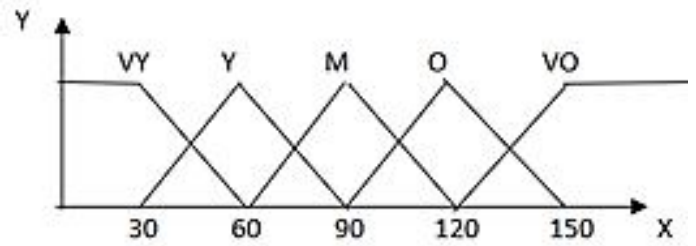

Figure 8: Membership Function for Criteria 4 - Reasoning and real solution

For the measuring pair of criteria, there is a goodness level can be seen in Figure 9. Membership with member (X) which intersect the axis $(\mathrm{Y})$ is unacceptable $(\mathrm{U})$, barely acceptable (BA), just acceptable (JA), good (G), very Good (VG) with the fuzzy values are respectively $(1,1,2),(1,2,3),(2,3,4),(3,4$, 5) and $(4,5,5)$.

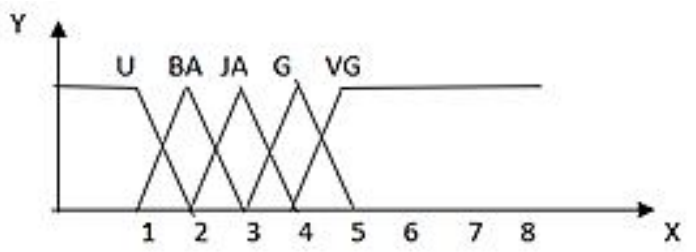

Figure 9: Goodness of criteria 4

Next, the fuzzy rule bases for Reasoning and Real Solution (RRS) VS Goodness are regulated via Rule 4 or listed in Table 6.

Rule 4: Fuzzy Rule Bases for Reasoning and Real Solution VS Goodness

IF (RRS is VY) THEN

Goodness is $U$

ELSEIF (RRS is VY) or (RRS is Y) THEN

Goodness is $\mathrm{U}$

ELSEIF (RRS is Y) THEN

Goodness is BA

ELSEIF (RRS is Y) or (RRS is M) THEN

Goodness is BA

ELSEIF (RRS is M) THEN

Goodness is JA

ELSEIF (RRS is M) or (RRS is $\mathrm{O}$ ) THEN

Goodness is JA

ELSEIF (RRS is O) THEN

Goodness is $\mathrm{G}$

ELSEIF (RRS is O) or (RRS is VO) THEN

Goodness is $\mathrm{G}$

ELSEIF (RRS VO) THEN

Goodness VG
Table 6: Reasoning and Real Solution VS Goodness

\begin{tabular}{|c|l|l|}
\hline No. & \multicolumn{1}{|c|}{ RRS } & Goodness \\
\hline 1. & VY & U \\
\hline 2. & VY or $\mathrm{Y}$ & U \\
\hline 3. & Y & BA \\
\hline 4. & Y or M & BA \\
\hline 5. & M & JA \\
\hline 6. & M or O & JA \\
\hline 7. & O & G \\
\hline 8. & O or VO & G \\
\hline 9. & VO & VG \\
\hline
\end{tabular}

Y

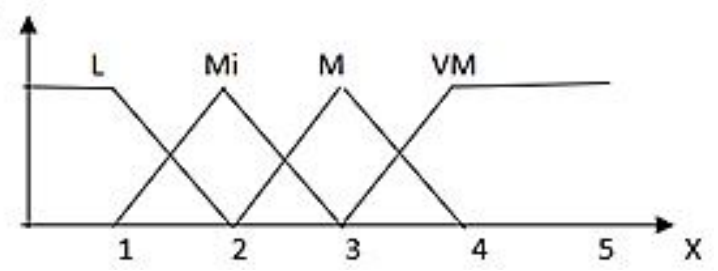

Figure 10: Membership Function for Criteria 5 - Years of service

For the measuring pair of criteria, there is a goodness level can be seen in Figure 10. Membership with member (X) which intersect the axis (Y) is low (L), middle (M), many $(\mathrm{M})$, very much $(\mathrm{VM})$ with the fuzzy value is $(1,1,2),(1,2$, $3),(2,3,4)$, and $(3,4,4)$.

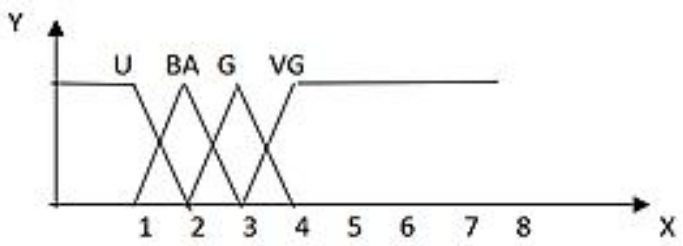

Figure 11: Goodness of criteria 5

Furthermore, the fuzzy rule bases for Years of Service VS Goodness are determined like in Rule 5 or listed in Table 7.

Rule 5: Fuzzy Rule Bases for Years of Service VS Goodness IF (Years of Service is L) THEN

(Goodness is U)

ELSEIF (Years of Service is L) or (Years of Service is Mi) THEN

Goodness is U

ELSEIF (Years of Service is Mi) THEN

Goodness is BA

ELSEIF (Years of Service is Mi) or (Years of Service is M) THEN

Goodness is BA

ELSEIF (Years of Service is M) THEN

Goodness is $\mathrm{G}$

ELSEIF (Years of Service is M) or (Years of Service is

VM) THEN

Goodness is $\mathrm{G}$

ELSEIF (Years of Service is VM) THEN

Goodness is VG 
Table 7: Years of Service VS Goodness

\begin{tabular}{|c|l|l|}
\hline No. & \multicolumn{1}{|c|}{ Years } & Goodness \\
\hline 1. & L & U \\
\hline 2. & L or Mi & U \\
\hline 3. & Mi & BA \\
\hline 4. & Mi or M & BA \\
\hline 5. & M & G \\
\hline 6. & M or VM & G \\
\hline 7. & VM & VG \\
\hline
\end{tabular}

Table 8: Sample Data for Marketers

\begin{tabular}{|l|c|c|c|c|c|}
\hline Marketer & EDU & VI & QOW & RRS & YS \\
\hline MK1001 & 2 & 27 & 19 & 30 & 6 \\
\hline MK1002 & 2 & 28 & 36 & 61 & 4 \\
\hline
\end{tabular}

The Table 8 is a sample of two marketers, where raw values of each of criteria / parameters are presented. Then we determined fuzzy values based on the data of each existing marketer. First, we determined the polar interpolation of this value, then proceed by determining the central of gravity with the formula as follows. Equation (3) is a formula for determining linear interpolation on marketer criteria. Also, equation (4) is a formula to determine Central of Gravity $(C \circ G)$ on the criteria of marketers.

$$
\begin{gathered}
Y=Y 0+(X-X 0) \frac{Y_{1}-\gamma 0}{X 1-X 0} \\
C O G=\frac{\left.\sum_{[}[F o t)(F G r d \theta)\right]}{\left.\Sigma_{F o t}\right]}
\end{gathered}
$$

This is a fuzzy interpolation value from criteria 1- education for each marketer, which determined the value of $\mathrm{CoG}$. Where the value of $C o G$ is a fuzzy value that will be processed in the next profile matching method.

\section{Fuzzy of Criteria Education}

For MK1001 - X=2, the numeric value in the base rule will be processed to get $\mathrm{Y}(\mathrm{W})$ value from MK1001. From equation (3) above, the $\mathrm{Y}(\mathrm{W})$ value is 0 . After getting the results of fuzzy interpolation of education criteria, then adjusted to the rule base criteria and inputted fuzzy interpolation values to be multiplied by the numbers in the Table 3 or Rule 1; where it means "IF Education is $(0 * 3)$ THEN Goodness is $(0 * 3)$ ".

The numerical value contained in the rule base is going to be processed to get CoG value of MK1001. The equation (4) is operated, and CoG produced is 0.00 . This is a fuzzy interpolation value from criteria education of MK1001, which determined the value of $C a G$. Where the value of $C o G$ is a fuzzy value that will be processed in the next profile matching method.

For MK1002 - X=2, the numeric value in the base rule will be processed to get $\mathrm{Y}(\mathrm{W})$ value from MK1002. Based on equation (3) formula, the $\mathrm{Y}(\mathrm{W})$ value is 0.00 . After getting the results of fuzzy interpolation of education criteria, then adjusted to the rule base criteria and inputted fuzzy interpolation values to be multiplied by the numbers in the Table 3 or Rule 1; "IF Education is $(0 * 30)$ THEN Goodness is (0*30)".

The numerical value contained in the rule base will be processed to get $C O G$ value of MK1002. The equation (4) is operated, and CoG produced is 0.00 . This is a fuzzy interpolation value from criteria education of MK1002, which determined the value of $\operatorname{CoG}$. Where the value of CoG is a fuzzy value that will be processed in the next profile matching method.

\section{Fuzzy of Criteria Verbalization Idea}

For MK1001 - X=25, the numeric value in the base rule will be processed to get $\mathrm{Y}(\mathrm{M})$ value from MK1001. According to calculation via equation (3), the $\mathrm{Y}(\mathrm{M})$ value is 1.00 . After getting the results of fuzzy interpolation of verbalization idea criteria, then adjusted to the rule base criteria and inputted fuzzy interpolation values to be multiplied by the numbers in the Table 4 Rule 2; "IF Verbalization Idea is (1*9) THEN Goodness is (1*9)".

The numerical value contained in the rule base will be processed to get CoG value of MK1001. The equation (4) is operated, and $C o G$ produced is 9.00. This is a fuzzy interpolation value from criteria verbalization idea of MK1001, which determined the value of CoG. Where the value of $C o G$ is a fuzzy value that will be processed in the next profile matching method.

For MK1002 - X=18, the numeric value in the base rule will be processed to get $\mathrm{Y}(\mathrm{JA})$ and $\mathrm{Y}(\mathrm{QL})$ value from MK1002. From equation (3) above, the value of Y(JA) obtained is 0.60 and the value of $\mathrm{Y}(\mathrm{QL})$ obtained is 0.40 . After getting the results of fuzzy interpolation of verbalization idea criteria, then adjusted to the rule base criteria and inputted fuzzy interpolation values to be multiplied by the numbers in the Table 4 or Rule 2; where "IF Verbalization Idea is $\left(0.6^{*} 5\right)$ or Verbalization Idea is $(0.4 * 7)$ THEN Goodness is $\left(0.6^{*} 6\right)$ ".

The numerical value contained in the rule base will be processed to get $C o G$ value of MK1002. The equation (4) is operated, and CoG produced is 5.87. This is a fuzzy interpolation value from criteria verbalization idea of MK1002, which determined the value of $\operatorname{CoG}$. Where the value of $C o G$ is a fuzzy value that will be processed in the next profile matching method.

\section{Fuzzy of Criteria Quantity of Work}

For MK1001 - X=19, the numeric value in the base rule will be processed to get $\mathrm{Y}(\mathrm{L})$ and $\mathrm{Y}(\mathrm{JA})$ value from MK1001. From equation (3), the value of $\mathrm{Y}(\mathrm{L})$ obtained is 0.10 and the value of $\mathrm{Y}(\mathrm{JA})$ obtained is 0.90 . After getting the results of 
fuzzy interpolation of quantity of work criteria, then adjusted to the rule base criteria and inputted fuzzy interpolation values to be multiplied by the numbers in the Table 5 or Rule 3 ; where "IF QOW is $(0.1 * 1)$ or QOW is $(0.9 * 3)$ THEN Goodness is $(0.9 * 2)$ ".

The numerical value contained in the rule base will be processed to get $C a G$ value of MK1001. The equation (4) is operated, and CoG produced is 2.89. This is a fuzzy interpolation value from criteria quantity of work for MK1001, which determined the value of $C o G$. Where the value of $\operatorname{CoG}$ is a fuzzy value that will be processed in the next profile matching method.

Then, for MK1002 $-X=30$, the numeric value in the base rule will be processed to get $\mathrm{Y}(\mathrm{M})$ value from MK1002. In accordance with equation (3), the $\mathrm{Y}(\mathrm{M})$ value is 1.00. After getting the results of fuzzy interpolation of quantity of work, then adjusted to the rule base criteria and inputted fuzzy interpolation values to be multiplied by the numbers in the Table 5 or Rule 3; where "IF QOW is $(1 * 5)$ THEN Goodness is $(1 * 5)$ ".

The numerical value contained in the rule base will be processed to get $C o G$ value of MK1002. The equation (4) is operated, and CoG produced is 5.00. This is a fuzzy interpolation value from criteria quantity of work for MK1002, which determined the value of $C o G$. Where the value of $\mathrm{CoG}$ is a fuzzy value that will be processed in the next profile matching method.

\section{Fuzzy of Criteria Reasoning and Real Solution}

For MK1001 - $X=30$, the numeric value in the base rule will be processed to get $\mathrm{Y}(\mathrm{VY})$ and $\mathrm{Y}(\mathrm{Y})$ value from MK1001. From equation (3) above, the value of $\mathrm{Y}(\mathrm{VY})$ obtained is 1 and the value of $\mathrm{Y}(\mathrm{Y})$ obtained is 0.00 . After getting the results of fuzzy interpolation of reasoning and real solution criteria, then adjusted to the rule base criteria and inputted fuzzy interpolation values to be multiplied by the numbers in the Table 6 or Rule 4; where "IF RRS is $(1 * 1)$ or RRS is $(0 * 3)$ THEN Goodness is $(1 * 2)$ ".

The numerical value contained in the rule base will be processed to get $\mathrm{CoG}$ value of MK1001. The equation (4) is operated, and CoG produced is (1.95). This is a fuzzy interpolation value from criteria reasoning and real solution of MK1001, which determined the value of $\operatorname{CoG}$. Where the value of $C O G$ is a fuzzy value that will be processed in the next profile matching method.

Moreover, for MK1002 - X=61, the numeric value in the base rule will be processed to get $\mathrm{Y}(\mathrm{Y})$ and $\mathrm{Y}(\mathrm{M})$ value from MK1002. From equation (3) above, the value of $\mathrm{Y}(\mathrm{Y})$ obtained is 0.03 and the value of $\mathrm{Y}(\mathrm{M})$ obtained is 0.96 . After getting the results of fuzzy interpolation of reasoning and real solution criteria, then adjusted to the rule base criteria and inputted fuzzy interpolation values to be multiplied by the numbers in the Table 6 or Rule 4; where "IF RRS is $(0.96 * 3)$ or RRS is $(0.03 * 5)$ THEN Goodness is $(0.96 * 4)$ ".

The numerical value contained in the rule base will be processed to get $C o G$ value of MK1001. The equation (4) is operated, and CoG produced is 0.64. This is a fuzzy interpolation value from criteria reasoning and real solution for MK1002, which determined the value of $C o G$. Where the value of $C o G$ is a fuzzy value that will be processed in the next profile matching method.

\section{Fuzzy of Criteria Years of Service}

For MK1001 - X=6, the numeric value in the base rule will be processed to get $\mathrm{Y}(\mathrm{VM})$ value from MK1001. From equation (3) above, the $\mathrm{Y}(\mathrm{VM})$ value is 1.00. After getting the results of fuzzy interpolation of years of service criteria, then adjusted to the rule base criteria and inputted fuzzy interpolation values to be multiplied by the numbers in the Table 7 or Rule 5 ; where "IF Years of Service is $(1 * 7)$ THEN Goodness is $(1 * 7)$ ".

The numerical value contained in the rule base will be processed to get $C o G$ value of MK1001. The equation (4) is operated, and CoG produced is 7.00. This is a fuzzy interpolation value from criteria years of service of MK1001, which determined the value of $C o G$. Where the value of $C o G$ is a fuzzy value that will be processed in the next profile matching method.

For MK1002 $-X=4$, the numeric value in the base rule will be processed to get $\mathrm{Y}(\mathrm{VM})$ value from MK1002. From equation (3), the $\mathrm{Y}(\mathrm{VM})$ value is 1.00 . After getting the results of fuzzy interpolation of years of service criteria, then adjusted to the rule base criteria and inputted fuzzy interpolation values to be multiplied by the numbers in the Table 7 or Rule 5; where "IF Years of Service is $(1 * 7)$ THEN Goodness is $(1 * 7)$ ".

The numerical value contained in the rule base will be processed to get $C o G$ value of MK1002. The equation (4) is operated, and CoG produced is 7.00. This is a fuzzy interpolation value from criteria years of service of MK1002, which determined the value of $C o G$. Where the value of $C O G$ is a fuzzy value that will be processed in the next profile matching method. The fuzzy results for each criterion is presented in Table 9. Then results of fuzzification will be processed by the profile matching method.

Table 9: Result of Fuzzy
\begin{tabular}{|l|c|c|c|c|l|}
\hline $\begin{array}{l}\text { Markete } \\
\text { r }\end{array}$ & EDU & VI & QOW & RRS & YS \\
\hline MK1001 & 0.00 & 9.00 & 2.89 & 1.95 & 7.00 \\
\hline MK1002 & 0.00 & 5.87 & 5.00 & 3.64 & 7.00 \\
\hline
\end{tabular}




\subsection{Determining Top-Marketers through PM}

After getting the fuzzy value, then dividing the aspects into two groups, namely Core Factor (CF) and Secondary Factor (SF). CF is the main factor in determining factors in the assessment process that can produce optimal performance, while SF is a secondary factor besides factors in main criteria [33] [42]. Please in Table 10. Then the next is to determine the gap value for each criterion (see in Table 11) and also the gap results are adjusted with the Table 12 .

Moreover, do to determine the value of CF and SF (see respectively Table 13 and 14), then calculate the average value of both. To calculate $C F$, use the following equation (5); where NCF is an average CF value, $\mathrm{NC}(\mathrm{a}, \mathrm{n})$ is a total number of $\mathrm{CF}$ values, and $\mathrm{IC}$ presents a number of $\mathrm{CF}$ items.

Table 10: Assessment Aspect

\begin{tabular}{|l|l|}
\hline Core Factor & Secondary Factor \\
\hline Verbalization idea & Education \\
\hline Reasoning and real solution & Years of service \\
\hline Quantity of work & \\
\hline
\end{tabular}

Table 11: Gap calculation for each criteria
\begin{tabular}{|l|r|r|r|r|c|}
\hline Marketer & VI & \multicolumn{1}{c|}{ RRS } & $\begin{array}{c}\text { QO } \\
\text { W }\end{array}$ & EDU & YS \\
\hline MK1001 & 9.00 & 1.95 & 2.89 & 0.00 & 7.00 \\
\hline MK1002 & 5.87 & 3.64 & 5.00 & 0.00 & 7.00 \\
\hline GAP & 4.00 & 6.00 & 4.50 & 3.00 & 4.50 \\
\hline MK1001 & 5.00 & -4.05 & -1.61 & -3.00 & 2.50 \\
\hline MK1002 & 1.87 & -2.36 & 0.50 & -3.00 & 2.50 \\
\hline
\end{tabular}

Table 12: Weight for each criteria

\begin{tabular}{|l|c|c|c|c|c|}
\hline Marketer & VI & RRS & QOW & EDU & YS \\
\hline MK1001 & $\begin{array}{c}0.0 \\
0\end{array}$ & 1.00 & 4.00 & 2.00 & 3.50 \\
\hline MK1002 & $\begin{array}{c}4.5 \\
0\end{array}$ & 3.00 & 5.00 & 2.00 & 3.50 \\
\hline
\end{tabular}

$$
N C F=\frac{\operatorname{ZNCSa} 3}{\operatorname{Re}}
$$

Whereas the SF calculation can be addressed in the formula in equation 6; where NSF is an average SF value, NS (a,n) is a total number of SF values, and IC symbolizes a number of SF items.

$$
N C F=\frac{\operatorname{2NC(an)}}{\operatorname{IiC}}
$$

Table 13: CF values

\begin{tabular}{|l|c|c|c|c|}
\hline Marketer & VI & RRS & QOW & CF Value \\
\hline MK1001 & 0.00 & 1.00 & 4.00 & 1.80 \\
\hline MK1002 & 4.50 & 3.00 & 5.00 & 3.60 \\
\hline
\end{tabular}

Table 14: SF values

\begin{tabular}{|l|c|c|c|}
\hline Marketer & EDU & YS & SF Value \\
\hline MK1001 & 2.00 & 3.50 & 2.80 \\
\hline MK1002 & 2.00 & 3.50 & 2.80 \\
\hline
\end{tabular}

Calculation of total value is obtained based on the calculation of $\mathrm{CF}$ and SF values in determining the ranking of each marketer. The total value is the ranking of each marketer in a certain position [42]. It is measured via equation (7); where $(\mathrm{a}, \mathrm{n})$ symbolizes a profile marketing and target value, $\mathrm{N}(\mathrm{a}, \mathrm{n})$ is a total value of the aspects, $\operatorname{NCF}(a, n)$ is a $\mathrm{CF}$ average value, $\operatorname{NSF}(\mathrm{a}, \mathrm{n})$ presents a SF average value, and $(\mathrm{X}) \%$ is a percent value entered

$$
N(a, n)=(x) \% N C F(a, n)+(x) \% N 5 F(a, n)
$$

Table 15: Ranking value

\begin{tabular}{|l|c|c|c|c|}
\hline Marketer & NCF & NSF & N(a,n) & Ranking \\
\hline MK1001 & 1.80 & 2.80 & $=(60 \% \times 1.8)+(40 \% \times 2.8)$ & 2.20 \\
\hline MK1002 & 3.60 & 2.80 & $=(60 \% \times 3.6)+(40 \% \times 2.8)$ & 3.28 \\
\hline
\end{tabular}

Based on Table 15, we can see that highest value was achieved by MK1002. Thus, that concerned had the right to be made as top-marketer.

\section{CONCLUSION AND FURTHERWORK}

Fuzzy logic helps to minimize the value of ambiguity. So, it is very suitable when juxtaposed with the profile matching method. Where profile matching emphasizes the ideal achievement, that the fuzzy input value is very appropriate to help realizing that ideal standard. Also, the combination of those methods was successfully operated to develop a decision support model for determining the best marketer with specific criteria.

It is also the case raised demand to be more professional by putting aside feelings and presumptions in deciding something. So, the appropriate method is needed to make it happen. Which the fuzzy profile matching is a solution that is able to handle it to be more rational.

\section{ACKNOWLEDGEMENT}

We would like to thank Bina Nusantara University who has supported and sponsored our studies and works, particularly Bina Nusantara Graduate Program, Master of Computer Science.

\section{REFERENCES}

1. V. Chouliaras, A. Gazepis, and T. Kargidis. (2015). Marketing's contribution to the profitability of Greek enterprises during the economic crisis, Procedia Economics and Finance, vol. 19, pp. 217-225, 2015. https://doi.org/10.1016/S2212-5671(15)00023-4

2. H. Lim, J. G. Choi, A. Akhmedov, and J. Chung. Predicting future trends of media elements in hotel marketing by using Change Propensity Analysis, International Journal of Hospitality Management, pp. 278-431, 2018. 
3. F. Y. Lo and N. Campos. Blending internet-of-things (IoT) solutions into relationship marketing strategies, Technological Forecasting and Social Change, vol. 137, pp. 10-18, 2018.

4. S. F. Slater, G. T. M. Hult, and E. M. Olson. (2010). Factors influencing the relative importance of marketing strategy creativity and marketing strategy implementation effectiveness, Industrial Marketing Management, vol. 39, no. 4, pp.551-559, 2010.

5. G. Büyüközkan and B. Ergün. Intelligent system applications in electronic tourism, Expert systems with applications, vol. 38, no. 6, pp. 6586-6598, 2011. https://doi.org/10.1016/j.eswa.2010.11.080

6. J. Tian, Y. Zhang and C. Zhang. Predicting consumer variety-seeking through weather data analytics, Electronic Commerce Research and Applications, vol. 28, pp. 194-207, 2018.

7. T. Turk, O. Kitapci, and I. T. Dortyol. The usage of geographical information systems (GIS) in the marketing decision making process: a case study for determining supermarket locations, Procedia-Social and Behavioral Sciences, vol. 148, pp. 227-235, 2014.

8. M. Moradi, A. Aghaie, and M. Hosseini. Knowledge-collector agents: Applying intelligent agents in marketing decisions with knowledge management approach, Knowledge-Based Systems, vol. 52, pp. 181-193, 2013.

9. C. Kiss and M. Bichler. Identification of influencers-measuring influence in customer networks, Decision Support Systems, vol. 46, no. 1, pp. 233-253, 2008.

10. S. L. France, M. S. Vaghefi, and H. Zhao. Characterizing viral videos: Methodology and applications, Electronic Commerce Research and Applications, vol. 19, pp. 19-32, 2016.

11. M. Ripollés and A. Blesa. International new ventures as "small multinationals": The importance of marketing capabilities, Journal of World Business, vol. 47, no. 2, pp. 277-287, 2012.

12. M. Yoshida, B. S. Gordon, M. Nakazawa, S. Shibuya, and N. Fujiwara. Bridging the gap between social media and behavioral brand loyalty, Electronic Commerce Research and Applications, vol. 28, pp. 208-218, 2018.

13. J. M. Peragón, A. Delgado, J. A. R. Díaz, and F. J. Pérez-Latorre. A GIS-based decision tool for reducing salinization risks in olive orchards, Agricultural Water Management, vol. 166, pp. 33-41, 2016.

14. M. Chica, Ó. Cordón, S. Damas, V. Iglesias, and J. Mingot. Identimod: Modeling and managing brand value using soft computing, Decision Support Systems, vol. 89, pp. 41-55, 2016.

15. C. Demergasso, R. Véliz, P. Galleguillos, S. Marín, M. Acosta, V. Zepeda, ... and J. Bekios-Calfa. Decision support system for bioleaching processes, Hydrometallurgy, vol. 181, pp. 113-122, 2018. https://doi.org/10.1016/j.hydromet.2018.08.009
16. B. G. Hwang, M. Shan, and K. Y. Looi. Knowledge-based decision support system for prefabricated prefinished volumetric construction, Automation in Construction, vol. 94, pp. 168-178, 2018.

17. A. W. Siddiqui, S. A. Raza, and Z. M. Tariq. A web-based group decision support system for academic term preparation, Decision Support Systems, vol. 114, pp. 1-17, 2018.

18. Z. Sun, J. Sun, and G. Meredith. Customer decision making in Web services with an integrated P6 model, Physics Procedia, vol. 24, pp. 1553-1559, 2012.

19. J. M. Laínez, G. V. Reklaitis, and L. Puigjaner. Linking marketing and supply chain models for improved business strategic decision support, Computers \& Chemical Engineering, vol. 34, no. 12, pp. 2107-2117, 2010.

20. A. G. Yeh and X. Shi. Case-based reasoning (CBR) in development control, International Journal of Applied Earth Observation and Geoinformation, vol. 3, no. 3, pp. 238-251, 2001.

21. Z. D. U. Durmusoglu. Assessment of techno-entrepreneurship projects by using Analytical Hierarchy Process (AHP), Technology in Society, vol. 54, pp. 41-46, 2018. https://doi.org/10.1016/j.techsoc.2018.02.001

22. A. Gnanavelbabu and P. Arunagiri. Ranking of MUDA using AHP and Fuzzy AHP algorithm, Materials Today: Proceedings, vol. 5, pp. 13406-13412, 2017.

23. C. Acar, A. Beskese, and G. T. Temur. Sustainability analysis of different hydrogen production options using hesitant fuzzy AHP, International Journal of Hydrogen Energy, vol. 43, no. 39, pp. 18059-18076, 2018.

24. N. Novita. Metode Fuzzy Tsukamoto Untuk Menentukan Beasiswa, SinkrOn, vol. 1, no. 1, 2017.

25. F. Gunawan, G. Wang, D. N. Utama, and S. Komsiyah. Decision Support Model for Supplier Selection Using Fuzzy Logic Concept, International Conference on Information Management and Technology, pp. 394-399, 2018.

26. D. N. Utama, A. Z. Taufan, A. S. G. Hartzani, A. L. Liani, N. Y. Anggraeni, and R. N. Amalina. Optimization based Decision Support System for Reconstructing the Traffic Road (Case Study: PI Intersection Traffic Road, Indonesia), International Journal of New Innovations in Engineering and Technology, vol. 6, no. 1, 2016.

27. J. W. Liu. Using big data database to construct new GFuzzy text mining and decision algorithm for targeting and classifying customers, Computers \& Industrial Engineering, 0360-8352, 2018.

28. Q. Zhou, Z. Xu, and N. Y. Yen. User sentiment analysis based on social network information and its application in consumer reconstruction intention, Computers in Human Behavior, 0747-5632, 2018.

29. A. Vafadarnikjoo, N. Mishra, K. Govindan, and K. Chalvatzis. Assessment of Consumers' Motivations to 
Purchase a Remanufactured Product by Applying Fuzzy Delphi Method and Single Valued Neutrosophic Sets, Journal of Cleaner Production, 0959-6526, 2018.

30. K. Howells and A. Ertugan. Applying fuzzy logic for sentiment analysis of social media network data in marketing, Procedia Computer Science, vol. 120, pp. 664-670, 2017.

31. S. Pami. Sistem Pendukung Keputusan Pemilihan Karyawan Terbaik Dengan Metode Promethee (Studi Kasus: PT. Karya Abadi Mandiri), Pelita Informatika: Informasi dan Informatika, vol. 16, no. 3, 2017.

32. Z. Tharo and A. P. U. Siahaan. Profile Matching in Solving Rank Problem, Electronics and communication Engineering, vol. 11, no. 5, pp. 73-76, 2016. https://doi.org/10.9790/2834-1105017376

33. Oktopanda. A Study of Decision Support System with Profile Matching, Informatics Management, pp. 47-48, 2017.

34. A. A. T. Susilo. Penerapan Metode Profile Matching pada Sistem Pendukung Keputusan Pemilihan Ketua Program Studi (STUDI Kasus: Program Studi Teknik Informatika STMIK Musi Rawas), JUITA: Jurnal Informatika, vol. 5, no. 2, pp. 87-93, 2018.

35. R. Nasriyah, Z. Arham, and Q. Aini. Profile matching and competency based human resources management approaches for employee placement decision support system (case study), Asian J. Appl. Sci, vol. 9, no. 2, pp. 75-86, 2016.

36. T. Susilo and A. Anto. Penerapan Metode Composite Performance Index (CPI) pada Pemilihan Hotel di Kota Lubuklinggau, Jurnal Rekayasa Sistem dan Teknologi Informasi, vol. 1, no. 3, pp. 204-210, 2017.

37. B. W. Sari. Perbandingan Metode Profile Matching Dan Simple Additive Weighting Pada Penentuan Jurusan Siswa Kelas X SMA N 2 Ngaglik, Data Manajemen dan Teknologi Informasi (DASI), vol. 16, no. $1,2015$.

38. A. Nurdianto, S. J. Hartati. And Y. M. Maulana. Rancang Bangun Sistem Pendukung Keputusan Penempatan Tenaga Pendidik Menggunakan Metode Profile Matching, Jurnal Sistem informasi dan Komputer Akuntansi, vol. 5, no. 2, pp. 1-8, 2016.

39. C. C. Escolar-Jimenez, K. Matsuzaki, and R. C. Gustilo. Intelligent shortlisting process for job applicants using fuzzy logic - based profiling, International Journal of Advanced Trends in Computer Science and Engineering, vol. 8, no. 3, pp. 567-572, 2019. https://doi.org/10.30534/ijatcse/2019/36832019

40. C. C. Escolar-Jimenez, K. Matsuzaki, and R. C. Gustilo. A neural-fuzzy network approach to employee performance evaluation, International Journal of Advanced Trends in Computer Science and Engineering, vol. 8, no. 3, pp. 573-581, 2019.

https://doi.org/10.30534/ijatcse/2019/37832019
41. P. M. Soni and V. Paul. A fuzzy based data mining approach for the loan credibility prediction system in co-operative banking sector, International Journal of Advanced Trends in Computer Science and Engineering, vol. 8, no. 3, pp. 815-820, 2019. https://doi.org/10.30534/ijatcse/2019/74832019

42. L. Sopianti and N. Bahtiar. Student Major Determination Decision Support Systems using Profile Matching Method with SMS Gateway Implementation, Jurnal Sains dan Matematika, vol. 23, no. 1, pp. 14-24, 2015. 